\title{
Chapter [x]. The EU's External Action after Lisbon: Competences, Policy Consistency and Participation in International Environmental Negotiations
}

Antonio Cardesa-Salzmann and Elisa Morgera

DISCLAIMER: This is a draft chapter. The final version will be available in Research Handbook on EU Environmental Law edited by Marjan Peeters and Mariolina Eliantonio, forthcoming 2019, Edward Elgar Publishing Ltd. The material cannot be used for any other purpose without further permission of the publisher, and is for private use only.

Mention Word count: 7885 words

\begin{abstract}
This chapter focuses on the external dimension of EU environmental law and discusses the main developments that the Lisbon Treaty brought in this particular area, in the light of the practice of the EU institutions and the Member States, as well as the case law of the Court of Justice of the European Union (CJEU). Accordingly, we will first sketch out the competence and legal bases for EU external environmental action. Against this backdrop, we will look into how the EU has implemented the mandate of environmental integration, in order to ensure the consistency of its external environmental policy with other areas of EU external action, such as in particular the Common Commercial Policy (CCP). Finally, we will assess how the EU participates in international environmental negotiations. The chapter concludes with an evaluation of the EU's track record as a global actor in international environmental governance.
\end{abstract}

\section{Introduction}

EU environmental law is a body of law that emanates from the EU treaties and institutions. As much as this opening statement seems obvious, it is nevertheless important to keep in mind that, 
while instruments are formally adopted by the European Union's institutions, their normative content and regulatory approaches are deeply interrelated with the domestic law of Member States and with international law. As Nicolas de Sadeleer points out, the intertwinement especially with international law has presently reached such an intensity that 'we no longer know whether EU law originates from international law or vice versa.'

The initial ad hoc pieces of secondary environmental legislation from the 1970s, as well as the title on European Environmental Policy that the Single European Act introduced into the EEC Treaty, were the result of the internal market's economistic logic. In Charlotte Burns' and Neil Carter's words, 'key elites accepted the need for environmental regulation at European level as a way to ensure harmonization and prevent unfair competition' throughout the Single European Market. ${ }^{2}$ Arguably, after several enlargements and amendments of EU primary law, this fundamental reality has not changed after the entry into force of the Lisbon Treaty in December 2009.

However, environmental impacts of ever more globalised economic activities are increasingly perceived as critical governance challenges at an international level. Therefore, the development of the environmental acquis was hardly to remain a confined, uniquely European phenomenon. Rather, from its very beginnings the European environmental policy has featured a clear external connection with international developments. Since the 1990s, moreover, the EU has become a key international actor in regional and global environmental negotiations and has even sought a role of global leadership in that field. ${ }^{3}$ At present, in view of the provisions introduced by the Lisbon Treaty, the sustainable development of the Earth, seeking to accommodate economic growth with social and environmental protection, is among the key objectives of the EU's external action. ${ }^{4}$ Over the years, the EU has more and more engaged in shaping and implementing international environmental regimes. Under the integration mandate enshrined in its primary law, ${ }^{5}$ moreover, the European Union has shaped a transversal environmental dimension across its external action at bilateral, inter-regional and global levels. ${ }^{6}$ More recently, this external policy deliberately

\footnotetext{
${ }^{1}$ Nicolas De Sadeleer, EU Environmental Law and the Internal Market (Oxford University Press 2014) 186.

${ }^{2}$ Charlotte Burns \& Neil Carter, 'Environmental Policy', in Erik Jones, Anand Menon and Stephen Weatherill (eds), The Oxford Handbook of the European Union (Oxford University Press 2012) 511-525, 514.

${ }^{3}$ Burns \& Carter (2012) o.c. 519.

${ }^{4}$ Arts. 3(5) and 21(2)(d), (f) and (g) TEU.

${ }^{5}$ Art. 11 TFEU.

${ }^{6}$ G. Marin Duran \& E. Morgera, Environmental Integration in the EU's External Relations. Beyond Multilateral Dimensions (Hart 2012).
} 
emphasises a strategy of global leadership in climate change policy to achieve a competitive, low carbon economy in $2050 .^{7}$

Therefore, in this chapter we will first sketch out the competence and legal bases for EU external environmental action in the light of the interpretation of the CJEU (Section 2). Against this backdrop, we will look into how the EU has implemented the mandate of integration of environmental concerns into all other policy areas, in order to ensure the consistency of its external environmental policy with other areas of EU external action, such as in particular the CCP (Section 3). Finally, we will assess how the EU participates in international environmental negotiations (Section 4). The chapter concludes with an evaluation of the EU's track record as a global actor in international environmental governance.

\section{Competence and legal bases for EU external environmental action}

\subsection{Overview}

Since its very inception, the European Environmental Policy has always had an outward, international dimension. Indeed, already in July 1977, the then European Communities ratified two sets of international environmental treaties. ${ }^{8}$ These comprised the 1976 Barcelona Convention for the protection of the Mediterranean Sea against pollution, together with the Protocol for the prevention of pollution of the Mediterranean Sea by dumping from ships and aircraft, as well as the 1976 Berne Convention for the protection of the Rhine against chemical pollution, together with an additional agreement for acceding the International Commission for the Protection of the Rhine against pollution. As was the case for the adoption of environmental legislation by the Council at the time, the above international agreements were adopted on the basis of implicit

\footnotetext{
${ }^{7}$ Communication from the Commmission to the European Parliament, the European Council, the Council, the European Economic and Social Committee, the Committee of the Regions and the European Investment Bank, 'A Clean Planet for all. A European strategic long-term vision for a prosperous, modern, competitive and climate neutral economy, $\operatorname{COM}(2018) 773$ final (28 November 2018), 21-22.

${ }^{8}$ Council Decision 77/585/EEC of 25 July 1977 concluding the Convention for the protection of the Mediterranean Sea against pollution and the Protocol for the prevention of the pollution of the Mediterranean Sea by dumping from ships and aircraft [1977] OJ L 240/1; Council Decision 77/586/EEC of 25 July 1997 concluding the Convention for the protection of the Rhine against chemical pollution and an Additional Agreement to the Agreement, signed in Berne on 29 April 1963, concerning the International Commission for the Protection of the Rhine against pollution [1977] OJ L 240/37.
} 
powers drawn from article 235 EEC Treaty, the precursor to article 352 TFEU. For the conclusion of the Berne Convention and the additional agreement, in addition, the Council also relied on the ERTA case law, as the convention was complementary to the implementation of Council Directive 76/464/EEC of 4 May 1976 on pollution caused by certain dangerous substances discharged into the aquatic environment of the Community. ${ }^{9}$ Indeed, in ERTA, the Court of Justice had held that

... each time the Community, with a view to implementing a common policy envisaged by the Treaty, adopts provisions laying down common rules, whatever form these may take, the Member States no longer have the right, acting individually or even collectively, to undertake obligations with third countries which affect those rules. ${ }^{10}$

Therefore, notwithstanding article 235 EEC Treaty, the ERTA doctrine laid the ground for an implicit, exclusive competence of the European Communities to engage in external relations under the aforementioned conditions. ${ }^{11}$ With the 1986 Single European Act, a title on the environment was introduced in the EEC Treaty, thus shaping a new community policy with its own legal bases, including one specifically for external action. Indeed, what has in the meantime become article 191(4) TFEU clearly states

Within their respective spheres of competence, the Union and the Member States shall cooperate with third countries and with the competent international organisations. The arrangements for Union cooperation may be the subject of agreements between the Union and the third parties concerned. [...]

The competence of the EU for external environmental policy has henceforth been footed on a predominantly explicit power. The option of resorting to implicit powers, however, remains open where necessary, as the TFEU now codifies the ERTA case law in EU primary law. ${ }^{12}$ These far reaching external powers of the EU match the overarching, ever more ambitious objectives that it has given itself over time also in the field of international relations. The EU has been explicitly recognized international legal personality ${ }^{13}$ and enunciated in its highest legal framework its ambition to contribute globally, amongst others, to 'the sustainable development of the Earth, ${ }^{14}$ as well as explicitly included environmental protection among the objectives for the EU external action ('foster the sustainable economic, social and environmental development of developing

\footnotetext{
${ }^{9}$ [1976] OJ L129/23.

${ }^{10}$ Case 22/70, Commission v Council [1971] ECLI:EU:C:1971:32.

${ }^{11}$ Ibid, para 18.

${ }^{12}$ Arts. 3(2) and 216(1) TFEU.

${ }^{13}$ Art. 47 TEU.

${ }^{14}$ Art. 3(5) TEU. 
countries' and to 'help to develop international measures to preserve and improve the quality of the environment and the sustainable management of global natural resources, in order to ensure sustainable development'). ${ }^{15}$ This reflects a pre-existing external dimension of the EU environmental policy, which is expressed in the TFEU as 'promoting measures at international level to deal with regional or worldwide environmental problems, and in particular combating climate change'. ${ }^{16}$

Over the years, the EU has indeed engaged extensively in multilateral environmental negotiations at global and regional levels, eventually concluding around fifty multilateral environmental agreements. ${ }^{17}$ This is not to say, however, that a series of legal issues have not risen over the past decades regarding the scope and inherent limitations to the EU's external powers in the field of environmental protection, especially after the revision of the power conferring provisions in EU primary law. ${ }^{18}$ In particular, the last major revision of the EU Treaties through the Lisbon Treaty has introduced a series of novelties with regards to the conferral of competences to the EU, as well as the exercise of external powers by the EU, that have impacted also the conduct of EU external environmental policy. ${ }^{19}$ Indeed, a significant portion of the EU's competences in the field of environmental protection are shared with the Member States. ${ }^{20}$ This power sharing arrangement is mirrored in the field of external action, where both the EU and the Member States have each the power for external environmental policy 'within their respective sphere of competence'. ${ }^{21}$ Yet, a number of issue areas remain with respect, in particular, to (1) the relationship between the shared, explicit external powers of the $\mathrm{EU}$ in the field of the environmental policy ${ }^{22}$ with the explicit exclusive competence derived from the Common Commercial Policy;23 (2) the enduring

\footnotetext{
${ }^{15}$ Art 21(2)(d) and (f) TEU. Note that these objectives are also applicable to the EU common foreign and security policy (art 23 TEU). See Marin Duran \& Morgera (2012) o.c. 29.

${ }^{16}$ Art 191(1) TFEU, the emphasis on climate change was added by the Lisbon Treaty. See Marin Duran \& Morgera (2012) o.c. 29.

${ }^{17}$ See <http://ec.europa.eu/environment/international_issues/agreements_en.htm> (accessed 4 April 2019).

${ }^{18}$ Piet Eeckhout, 'Express and Implied Competences under the TFEU', EU External Relations Law (Oxford University Press 2011).

${ }^{19}$ D Van Eeckhoutte \& Tim Corthaut, 'The Participation of the EU and Its Member States in Multilateral Environmental Negotiations Post Lisbon’ (2017) Yearbook of European Law 36, 749-809.

${ }^{20}$ Art. 4(2)(e) TFEU.

${ }^{21}$ Art. 191(4) TFEU.

${ }^{22}$ Art. 191(4) TFEU.

${ }^{23}$ Arts. 3(1)(e) and 207 TFEU. Together with the CCP, the conservation of marine biological resources under the Common Fisheries Policy (CFP) is another area of exclusive competence of the EU (art. 3(1)(d) TFEU), with evident connections to the EU's external environmental policy. On that basis, the EU has over time concluded a significant number of bilateral and multilateral agreements, including bilateral Sustainable Fisheries Partnership Agreements,
} 
significance of the implicit, exclusive competence based on the ERTA doctrine; and (3) the relevance of the duty of sincere cooperation under article 4(3) TEU in the conduct of EU external environmental policy as a matter of shared competence with Member States. ${ }^{24}$

2.2 Shared, explicit external powers of environmental policy and exclusive, explicit powers of the $C C P$

Most international environmental treaties, to which the EU is a party, feature policies and regulatory approaches that foresee restrictions and supervision of international trade and/or transboundary movements of controlled commodities. This is the case, for instance, of the 1973 Convention on International Trade in Endangered Species of Fauna and Flora (CITES), the 1987 Montreal Protocol on Ozone Depleting Substances, the 1989 Basel Convention on Transboundary Movements of Hazardous Wastes and their Disposal, the 1998 Rotterdam Convention on Hazardous Chemicals, the 2000 Cartagena Protocol on Biosafety, the 2001 Stockholm Convention on Persistent Organic Pollutants, or the 2013 Minamata Convention on Mercury. The trade control measures envisaged in these treaties are crucial for fulfilling the regimes' underlying objectives of environmental protection. From the perspective of the legal basis for their ratification by the EU and its Member States, however, the question arose whether these treaties had to be concluded as 'mixed agreements' under article 191(4) TFEU or whether the EU's (exclusive) external competence under the CCP was also relevant, given the significant external trade component of those regimes.

As so often with EU competences and the choice of legal bases, the answer to this question is not clear cut and turns out to be quite casuistic. In accordance with the Court of Justice's general case law regarding the choice between (potentially) concurring legal bases initiated with the Titanium Dioxide case, ${ }^{25}$ the pertinence of either legal basis (or indeed both) depends very significantly on objective factors amenable to judicial review, such as the aim and the actual regulatory content of

Regional Fisheries Management Organisations (RFMOs), the UN Convention on the Law of the Sea, as well as different instruments adopted under the aegis of the UN Organisation for Food and Agriculture (FAO), of which the EU is a member. See David Langlet \& Said Mahmoudi, EU Environmental Law and Policy (Oxford University Press 2016) 126; Hubert Zimmermann, 'Balancing Sustainability and Commerce in International Negotiation: The EU and Its Fisheries Partnership Agreements' (2017) Journal of European Public Policy 24(1), 135-155.

${ }^{24}$ Suzanne Kingston, Veerle Heyvaert and Aleksandra Cavoski, European Environmental Law (Cambridge University Press 2017) 22-25.

${ }^{25}$ Case C-300/89, Commission v Council [1991] ECLI:EU:C:1991:244. 
the international treaty that the EU and/or the Member States intend to conclude. ${ }^{26}$ As regards in particular the above mentioned set of international treaties for environmental protection, which rely heavily on trade-related measures, the Court of Justice considered article 192 TFEU to be the adequate legal basis for the conclusion of the Cartagena Protocol on Biosafety, ${ }^{27}$ whereas it ruled that the conclusion of the Rotterdam Convention had to be effectuated on the concurrent basis of articles 192 and 207 TFEU. $^{28}$

In the former case, the Court of Justice concluded from the examination of the context, aim and content of the Cartagena Protocol '... that its main purpose or component is the protection of biological diversity against the harmful effects which could result from activities that involve dealing with LMOs, in particular from their transboundary movement. ${ }^{29}$ With respect to the latter treaty, however, the Court held that in contrast with the Cartagena Protocol, in the context of which 'trading in [living modified organisms] is ... merely one of the aspects governed by that protocol', the trade in the hazardous chemical substances included within the scope of application of the Rotterdam Convention 'constitutes the element upon which the application of the [prior informed consent] procedure is conditional. ${ }^{30}$ The Court concluded this line of reasoning by stating that,

[a]s defined in the Convention, that [prior informed consent] procedure also involves a number of measures that must be classified as measures 'governing' or 'regulating' international trade in the products concerned and therefore fall within the scope of the common commercial policy. ${ }^{31}$

As we shall see in subsequent sections, the above considerations are crucially relevant for determining not only the decision-making procedure in order to conclude international treaties in the field of environmental policy on behalf of the EU, but also for the role of the EU's delegation within the relevant forums of international environmental governance, in which the implementation of those treaties is shaped. ${ }^{32}$

${ }^{26}$ Case C-269/97, Commission v Council [2000] ECLI:EU:C:2000:183.

${ }^{27}$ Opinion 2/00 [2001] ECLI:EU:C:2001:664.

${ }^{28}$ Case C-94/03, Commission v Council [2006] ECLI:EU:C:2006:2.

${ }^{29}$ Opinion 2/00, para 34.

${ }^{30}$ Case C-94/03, para 45.

${ }^{31}$ Ibid, para 46.

${ }^{32}$ Art. 218 TFEU. See section 4 below. 


\subsection{The enduring significance of the ERTA doctrine for EU external environmental policy}

The question around the significance of the ERTA doctrine in the context of the EU's external environmental policy was at the heart of the more recent Green Energy case. ${ }^{33}$ In that case, the Italian Consiglio di Stato requested a preliminary ruling amongst other questions on the compatibility with EU law of a bilateral agreement concluded between Italy and Switzerland, on the basis of which Italian domestic legislation exempted green energy imported from the Switzerland from the green certificates scheme adopted pursuant to article 5 of the Renewable Energy Directive (Directive 2001/77/EC). ${ }^{34}$ To the extent that this piece of EU legislation had vastly harmonized the regulation of the renewable energy sector across Member States, the issue arose about the extent to which Member States were able of entering individually into international commitments under the ERTA doctrine and article 3(2) TFEU. The Court of Justice held that the bilateral agreement '... [was] liable to alter the scope of the common rules contained in Article $5^{35}$ of the Renewable Energy Directive, hence ruling that '[o]n a proper construction of the [TFEU], having regard to the provisions of Directive 2001/77/EC ..., the [EU] enjoys exclusive external competence precluding a provision of national law, such as that at issue in the main proceedings', ${ }^{36}$

It is important to bear in mind, however, that the degree of regulatory harmonization that is required in order for the implicit, exclusive external competence under the ERTA doctrine to rise is qualified. As can be inferred from the Green Energy case, the ERTA effect kicks in whenever international obligations entered into individually by a Member State with a third country can be held liable for altering the operation of the common rules established in a given sector for the internal market. It does not come into effect, however, if the degree of regulatory harmonization is only partial. This was found by the Court of Justice in Opinion 2/00 when it rejected the Commission's argument that the EU legislation related to genetically modified organisms at the

\footnotetext{
${ }^{33}$ Case C-66/13, Green Energy Network SpA v Autorità per l'energia elettrica e il gas [2014] ECLI:EU:C:2014:2399.

${ }^{34}$ Directive 2001/77/EC of the European Parliament and of the Council of 27 September 2001 on the promotion of electricity produced from renewable energy sources in the internal electricity market [2001] OJ L 283/33. In the meantime, this Directive has been repealed and substituted by Directive 2009/28/EC of the European Parliament and of the Council of 23 April 2009 on the promotion of the use of energy from renewable sources and amending and subsequently repealing Directives 2001/77/EC and 2003/30/EC [2009] OJ L 140/16.

${ }^{35}$ Case C-66/13, para 49.

${ }^{36}$ Ibid, para 76.
} 
time ${ }^{37}$ provided implicit, exclusive competence to the EU in order to conclude the Cartagena Protocol. In that occasion, the Court held that 'the harmonisation achieved at Community level in the Protocol's field of application covers in any event only a very small part of such a field'. ${ }^{38}$

van Eeckhoutte and Courthaut argue that Opinion 2/00 has led to a marginalisation of article 191(4) TFEU as a legal basis for the conclusion of international environmental agreements, as opposed to article 192(1) or, the case being, also 192(2) TFEU in combination with article 3(2) TFEU (ERTA doctrine) ${ }^{39}$ Moreover, the increasing harmonization of legislation across the EU in the fields of energy and climate change on the basis of what has now become article 194 TFEU, has also expanded the ambit of the implied, exclusive competence of the EU under the ERTA doctrine. ${ }^{40}$

\subsection{The EU's external environmental powers and the autonomy of Member States}

With the exception of possible interactions with the aforementioned legal bases that provide either explicit or implicit exclusive external competence to the EU, its external competence in matters related to environmental protection is shared with Member States under article 191(4) TFEU. As the closing sentence of this latter provision states, '[t]he previous subparagraph shall be without prejudice to Member States' competence to negotiate in international bodies and to conclude international agreements.' Member States do therefore enjoy a certain degree of autonomy to pursue their own angles within their respective external environmental policies. This autonomy, nevertheless, finds an evident limitation in the principles of institutional balance and the duty of sincere cooperation, ${ }^{41}$ which have now been enshrined un EU primary law under article 4(3) TEU.

\footnotetext{
${ }^{37}$ Council Directive 90/219/EEC of 23 April 1990 on the contained use of genetically modified micro-organisms [1990] OJ L 117/1; Council Directive 90/220/EEC of 23 April 1990 on the deliberate release into the environment of genetically modified organisms [1990] OJ L 117/15; and Directive 2001/18/EC of the European Parliament and of the Council of 12 March 2001 on the deliberate release into the environment of genetically modified organisms and repealing Council Directive 90/220/EEC [2001] OJ L 106/1.

${ }^{38}$ Opinion 2/00, para 46.

${ }^{39}$ Van Eeckhoutte \& Corthaut (2017) o.c. 759-60; see more generally on the post-Lisbon development of the ERTA case law Merijn Chamon, 'Implied Exclusive Powers in the ECJ's Post-Lisbon Jurisprudence: The Continued Development of the ERTA Doctrine' (2018) Common Market Law Review 55(4) 1101-1141.

${ }^{40}$ Hans Vedder, 'The Formalities and Substance of EU External Environmental Competence: Stuck between Climate Change and Competitiveness' in Elisa Morgera (ed), The External Environmental Policy of the European Union (Cambridge University Press 2012).

${ }^{41}$ In the MOX Plant case, the Court of Justice held Ireland liable for a breach of its duty of loyal cooperation under EU primary law, for submitting its dispute with the United Kingdom over the radioactive pollution of the Irish Sea from the Sellafield Plant to the International Tribunal on the Law of the Sea under the UN Convention on the Law of the Sea. The Court of Justice held that the resort to these international adjudicative procedures did not respect its
} 
In the PFOS (Perfluorooctane sulfonate) judgment, ${ }^{42}$ the Grand Chamber of the Court of Justice ruled that Sweden had breached its duty of sincere cooperation with the EU institutions and other Member States in the context of multilateral environmental negotiations in the Conference of the Parties (COP) of the Stockholm Convention on Persistent Organic Pollutants. As Marise Cremona highlighted, the case underscored the constraints imposed by the duty of loyal cooperation on Member States to introduce 'more stringent protective measures' externally by way of unilateral international action when the EU and Member States act in multilateral environmental fora under an a mixed agreement on the basis of shared competence. ${ }^{43}$ Notwithstanding the fact that Sweden's unilateral proposal for a more stringent protective measure under the Stockholm Convention on Persistent Organic Pollutants preceded an EU proposal on the matter and regardless of Sweden's efforts through Union mechanisms to achieve a joint proposal, the Court still held that Sweden had 'dissociated itself' from a common strategy that was being formulated within the Council and that its unilateral proposal under the MEA could have 'had potential legal consequences for the Union as a party' to that MEA that 'would have had to be reflected in Union legislation,' as well as undermining the unity of the Union's external representation as a party to the MEA. ${ }^{44}$

\section{Environmental integration in the EU's external relations}

Article 11 TFEU obliges the EU political institutions to integrate environmental protection requirements into all Union policies and activities, which includes external ones. This can also be derived from the general requirements for EU external action: Articles 3(5) TEU, which provides that 'in its relations with the wider world' the EU 'shall contribute to ... the sustainable development of the Earth, ... the strict observance and the development of international law' and 21(2) TEU, which includes among the objectives, values and principles for all EU external action 'help to develop international measures to preserve and improve the quality of the environment and the sustainable management of global natural resources, in order to ensure sustainable

exclusive competence under the EURATOM Treaty. See Case C-459/03 Commission v Ireland [2006] ECLI:EU:C:2006:345, para 169.

${ }^{42}$ Case C-246/07, Commission v Sweden [2010] ECLI:EU:C:2010:203.

${ }^{43}$ Marise Cremona, 'Coherence and EU External Environmental Policy', in Elisa Morgera (ed), The External Environmental Policy of the European Union (Cambridge University Press 2012) 33-54.

${ }^{44}$ Case C-246/07, para. 92-104. Cremona (2012) o.c. 41-45. 
development' ${ }^{45}$ 'foster the sustainable economic, social and environmental development of developing countries, with the primary aim of eradicating poverty'46 and 'assist populations, countries and regions confronting natural or man-made disasters' ${ }^{47}$ These objectives apply to all fields of EU external action (common foreign and security policy, development, trade and cooperation policies), as well as in the external aspects of the agricultural, fisheries, transport and energy policies. ${ }^{48}$ The EU is furthermore called upon to promote 'multilateral solutions to common problems' as well as 'an international system based on stronger multilateral cooperation and good global governance, ${ }^{49}$ which can be read as including the development of international environmental law and governance. ${ }^{50}$ While all these provisions do not attribute priority to environmental requirements, they entail a duty (Art. 11 TFEU) and an objective to consider environmental concerns as a matter of policy integration, the effect of which need to be assessed on a case-by-case basis due to the ample discretion left to the EU legislative and executive 'with which the EU judiciary is unlikely to interfere. ${ }^{51}$

The relevance of these provisions can be discussed in particular with reference to the EU external trade policy. Since 2006, the EU external trade policy has developed more systematic tools for environmental integration due to a combination of factors: the limited results of the EU's efforts to address environmental concerns at the multilateral level (notably under the WTO) and the opportunity to use the EU's market and economic power to 'export' its own environmental standards through unilateral and bilateral approaches to trade cooperation. ${ }^{52}$ Thus, negotiations on a new wave of 'competitiveness-driven' Free Trade Agreements (FTAs) was launched, which included the incorporation of 'cooperative provisions in areas related to labour standards and environmental protection'. ${ }^{53}$ These agreements have included clauses on climate change,

\footnotetext{
${ }^{45}$ Art 21(2)(f) TEU (emphasis by authors)

${ }^{46}$ Art 21(2)(d) TEU (emphasis by authors).

${ }^{47}$ Art 21(2)(g) TEU.

${ }^{48}$ Art 21(3) TEU.

${ }^{49}$ Article 21(2)(h) TEU.

${ }^{50}$ Marin Duran \& Morgera (2012) o.c. 43.

51 ibid.

52 Marise Cremona, 'The Union as a Global Actor: Roles, Models and Identity' (2004) Common Market Law Review 41(2), 553-573, 557; Marin Duran and Morgera (n 48) xx.

53 European Commission, 'Working paper on global Europe - competing in the world. A contribution to the EU's growth and job strategy SEC (2006) 1230, endorsed by the Council, 'Conclusions on Global Europe - competing in the world', Council Doc. 14799/06 (13 November 2006), 12.
} 
biodiversity, and other global MEAs that are related to trade ${ }^{54}$ but also support the EU's position in multilateral environmental negotiations, ${ }^{55}$ mainly fostering a cooperative approach in a conscious effort to distance the EU approach from that of US bilateral trade agreements. ${ }^{56} \mathrm{In}$ parallel, the EU has relied on prior assessments (Sustainability Impact Assessments for trade agreements, and Strategic Environmental Assessments /Environmental Impact Assessments for its external funding) to support a more systematic and transparent balancing between environmental and other objectives of the EU's external policies. ${ }^{57}$

Compliance with MEAs is being more systematically supported as part of the trade and sustainable development chapter (through 'best-endeavours' commitments, cooperation measures, and specific institutional mechanisms), but not as a fully-enforceable legal obligation. They establish a specialised Committee (or Sub-committee) to oversee the implementation of such a chapter, as well as special procedures for settling trade and environment disputes, requiring the involvement of environmental experts and also allowing for advice to be sought from MEA Secretariats. As with other EU agreements, they tend to favour decision-making by consensus and dispute settlement through consultations (though arbitration is also available). ${ }^{58}$ These agreements, in addition, seek to allow for public participation more systematically, including specific procedural guarantees or adjustments to the institutional structure of the bilateral/inter-regional partnership or association. $^{59}$

The actual effects of EU bilateral efforts to support multilateralism are quite uneven in different areas of environmental cooperation, and remain to be further studied, including from an

\footnotetext{
${ }^{54}$ Rok Žvelc, 'Environmental Integration in EU Trade Policy: The Generalised System of Preferences, Trade Sustainability Impact Assessments and Free Trade Agreements' in Elisa Morgera (ed), The External Environmental Policy of the European Union (Cambridge University Press 2012) 174-203.

${ }_{55}^{55}$ Marin Duran \& Morgera (2012) o.c..

${ }^{56}$ Sikina Jinnah \& Elisa Morgera, 'Environmental Provisions in American and EU Free Trade Agreements: A Preliminary Comparison and Research Agenda' (2013) Review of European, Comparative \& International Environmental Law 22(3) 324-339; E Morgera, 'Bilateralism at the Service of Community Interests? Non-Judicial Enforcement of Global Public Goods in the Context of Global Environmental Law' (2012) European Journal of International Law 23(3) 743-767.

${ }^{57}$ Marin Duran \& Morgera (2012) o.c. 234-253 and 173-190.

${ }^{58}$ By way of example, see EU-Singapore Free Trade Agreement (signed 19 October 2018, not yet in force), chapter 12, arts. 12.16 and 12.17. See also chapters 14 and 15.

${ }^{59}$ See e.g. EU-Singapore Free Trade Agreement, art. 12.15 (4) and (5).
} 
international law perspective ${ }^{60}$ and from the viewpoint of their interface with human rights protection, which is another goal of EU external policies. ${ }^{61}$

This increasing degree of integration of social and environmental protection concerns into the formulation of the EU's external action, especially in the context of the $\mathrm{CCP}$, has once again spurred anxiety by some Member States about the fact that the EU might be pursuing external environmental policy goals on the basis of an exclusive competence that has not been granted under articles 191(4) and 192(1) TFEU. This is particularly the case of the aforementioned new generation FTAs, which include very detailed sustainable development chapters. ${ }^{62}$

In its Opinion 2/15, of 16 May 2017, the Court had to address a series of observations by the Council and the Member States in order to clarify whether chapter 13 (on sustainable development) of the EU-Singapore FTA did fall within the exclusive competence of the EU under article 207 TFEU, or whether it would fall under the shared competence under article 191(4) TFEU. ${ }^{63}$ The Court relied as usual on a systematic interpretation of articles 21 TEU, 9, 11, 205 and 207 TFEU in order to crucially state that the objective of sustainable development 'forms an integral part of the common commercial policy. ${ }^{64}$ According to the Court, the integration mandate means that the concerns for social protection of workers and for environmental protection have to be built into the objectives of the CCP and that

it would ... not be coherent to hold that the provisions liberalising trade between the European Union and a third State fall within the common commercial policy and that those which are designed to ensure that the requirements of sustainable development are met when that liberalisation of trade takes place fall outside it. ${ }^{65}$

At the same time, the Court held the view that the sustainable development chapter of the FTA itself does not regulate the social protection of workers and environmental protection, but rather ensures that the conduct of trade between the signatory parties is conducted in such a way as to respect and comply with international obligations signed up to by both parties under other

\footnotetext{
${ }^{60}$ Elisa Morgera, 'The EU and Environmental Multilateralism: The Case of Access and Benefit-Sharing and the Need for a Good-Faith Test' (2014) Cambridge Yearbook of European Legal Studies 16, 109-142.

${ }^{61}$ Elisa Morgera, 'Protecting Environmental Rights through the Bilateral Agreements of the European Union: Mapping the Field' in Federico Lenzerini and Ana Filipa Vrdoljak (eds), International law for common goods: normative perspectives on human rights, culture and nature (Hart 2014) 421-441.

${ }^{62}$ See EU-Singapore Free Trade Agreement, chapter 12.

${ }^{63}$ Opinion 2/15, EU-Singapore Free Trade Agreement [2017] ECLI:EU:C:2017:376, para 22.

${ }^{64}$ Ibid, para 147.

${ }^{65}$ Ibid, para 163.
} 
international agreements in those fields. ${ }^{66}$ The inclusion of sustainable development chapters of the likes of that in the EU-Singapore FTA does therefore not concern the exclusive competence of the EU under the CCP and article 207 TFEU.

Finally, it is noteworthy that the integration of sustainable development and, more specifically, of environmental considerations into the EU's external trade policy has consolidated and increased in ambition over time. The 2016 Global Strategy, for instance, identifies a new priority area with regard to sustainable development in the marine environment, by making reference to the 'universalisation and implementation of the UN Convention of the Law of the Sea', as well as the promotion of 'the conservation and sustainable use of marine resources and biological diversity and the growth of the blue economy by working to fill legal gaps and enhancing ocean knowledge and awareness,' as well as to global maritime security as a way of ensuring trading routes and access to natural resources. ${ }^{67}$

\section{The participation of the $\mathrm{EU}$ in international environmental negotiations}

Given the predominantly 'mixed' or 'shared' nature of the external powers of the EU in the field of environmental policy, the representation of the EU and the Member States in international environmental negotiations has been quite a complex matter. The lack of consistency and coordination between the respective delegations from the Member States and the EU itself has often hindered them from operating in those international forums in a strong and consistent way, as a global actor. The clearest example of the failure of the EU and its Member States to act in a consistent and coordinated way was at the $15^{\text {th }}$ Conference of the Parties to the UN Convention on Climate Change, held in Copenhagen in December 2009, shortly after the entry into force of the Lisbon Treaty. On that occasion, the inability of Member States' and the EU's delegations to coordinate effectively led to their marginalisation within the negotiating process and cast a significant shadow over its ability to exert 'leadership' in international climate change negotiations. ${ }^{68}$ Arguably, the EU and the Member States have learned from the somewhat

\footnotetext{
${ }^{66}$ Ibid, paras 155-6.

${ }^{67}$ Shared Vision, Common Action: A Stronger Europe - A Global Strategy for the European Union's Foreign and Security Policy (June 2016), 41. At <https://eeas.europa.eu/sites/eeas/files/eugs_review_web_0.pdf $>$ (accessed 5 April 2019).

${ }^{68}$ Sebastian Oberthür, 'The European Union's Performance in the International Climate Change Regime' (2011) Journal of European Integration 33(6), 667-682.
} 
traumatic experience from December 2009 and have performed much better in the following stages of the climate change negotiations. ${ }^{69}$ This evolution is, however, the result of a learning process that has required finding a pragmatic interpretation of the institutional and procedural novelties that the Lisbon Treaty offers for EU external action in a context of 'mixity', ${ }^{70}$ as is the case in international multilateral environmental negotiations.

Indeed, the latest major revision of EU primary law operated through the Lisbon Treaty has tried to address the aforementioned issues of EU external representation, seeking to improve coordination and increase the visibility of the EU in global forums. ${ }^{71}$ While articles 191(4) and 192(1) TFEU provide the substantive legal basis for EU external environmental policy, as discussed in the previous section, article 218 TFEU lays down the procedural legal basis. ${ }^{72}$ According to article $218 \mathrm{TFEU}$, the Commission holds the initiative for submitting to the Council recommendations for the adoption of a decision authorising the opening of negotiations and the nomination of a Union negotiator or head of the Union's negotiating team. ${ }^{73}$ However, the actual decisions on authorising the opening of negotiations, the adopting of negotiating directives and, eventually, authorising the agreements' signature and concluding it, belong all to the remit of the Council. ${ }^{74}$ The default decision-making procedure foreseen in this context is qualified majority voting, unless the agreement to be concluded covers a field for which unanimity is required for the adoption of an EU act. ${ }^{75}$ Any decision of concluding the agreement, nevertheless, crucially requires the consent of the European Parliament for any 'agreements covering fields to which ... the ordinary legislative procedure applies' ${ }^{76}$ which is overwhelmingly the case of the legal bases of the EU's environmental policy. ${ }^{77}$ Where the special legislative procedure applies and the

\footnotetext{
${ }^{69}$ Claire Dupont, Sebastian Oberthür and Katja Biedenkopf, 'Climate Change: Adapting to Evolving Internal and External Dynamics', European Union External Environmental Policy (Springer International Publishing 2018) 105124; Sebastian Oberthür and Lisanne Groen, 'Explaining Goal Achievement in International Negotiations: The EU and the Paris Agreement on Climate Change' (2018) Journal of European Public Policy 25(5), 708-727.

${ }^{70}$ Alan Dashwood, 'Mixity in the Era of the Treaty of Lisbon' in Christophe Hillion and Panos Koutrakos (eds), Mixed Agreements Revisited. The EU and its Member States in the World (Hart 2010) 351-366.

${ }^{71}$ Art. 221 TFEU.

72 Tom Delreux, The EU as International Environmental Negotiator (Routledge 2011) 18-23.

${ }^{73}$ Art. 218(3) TFEU.

${ }^{74}$ Art. 218 (2) and (4)-(6) TFEU.

${ }^{75}$ Art. 218(8) TFEU. Unanimity is required for decision-making on any of the areas covered by art. 192(2) TFEU.

${ }^{76}$ Art. 218 (6)(a)(v) TFEU.

${ }^{77}$ Arts. 192(1) and 194 TFEU.
} 
European Parliament's consent is not required ${ }^{78}$ the decision for concluding an international agreement only requires the Parliament's consultation. ${ }^{79}$

In the case of 'mixed agreements' allowing the joint participation of the EU and its Member States, ${ }^{80}$ which is the vast majority of multilateral environmental agreements, the Member States take part in the negotiation process with the European Commission, as well as concluding and ratifying the agreement in question in accordance with each Member State's constitutional requirements. The EU's participation has been accommodated, as a 'regional economic integration organisation' (REIO), through the so-called REIO clauses ${ }^{81}$ However, even after the entry into force of the Lisbon Treaty, EU primary law only deals with the external representation of the EU in areas of its competence ${ }^{82}$ and therefore addresses this 'mixity ${ }^{83}$ of the EU's participation in international multilateral environmental forums in quite a minimalistic way: the Council, on a proposal from the Commission, establishes the positions to be adopted on the Union's behalf 'in a body set up by an agreement' ${ }^{84}$ The Council may also authorise the EU's negotiator or negotiating team to approve on behalf of the EU any modifications to the agreement adopted following a simplified procedure or a decision of a relevant treaty body. ${ }^{85}$ Article 218 TFEU, however, does not provide any explicit guidance as to the coordination with Member State delegations in such contexts of 'mixity'.

It is important to keep in mind, moreover, that article 218 TFEU only covers international negotiations leading to the adoption of an international legally binding instruments. Crucially, negotiations not aimed at adopting such a legally binding instrument, as is usually the case within treaty-bodies of multilateral environmental agreements (MEA), such as the Conference of the Parties (or indeed any subsidiary body thereof) are not covered by the procedures set out in article 218 TFEU. Rather, as van Eeckhoutte and Corthaut argue, these aspects of the conduct of

\footnotetext{
${ }^{78}$ E.g. in the areas covered by art. 192(2) TFEU.

${ }^{79}$ Art. 218(6)(b) TFEU.

${ }^{80}$ Note that 'mixed agreements' are not explicitly recognised in the TFEU and no specific procedure is thus found for their conclusion.

${ }^{81}$ See generally Ludwig Krämer, 'Regional Integration Organizations: The European Union as an Example' in Daniel Bodansky, Jutta Brunnee and Ellen Hey (eds), The Oxford Handbook of International Environmental Law (Oxford University Press 2007) 853-876.

${ }^{82}$ Van Eeckhoutte \& Corthaut (2007) o.c. 807.

${ }^{83}$ Dashwood (2010) o.c..

${ }^{84}$ Art. 218(9) TFEU.

${ }^{85}$ Art. 218(7) TFEU.
} 
international environmental negotiations on behalf of the EU for which the EU Treaties provide little guidance ought to be addressed from the perspective of general principles, such as the principle of inter-institutional balance ${ }^{86}$ and the principle of sincere cooperation ${ }^{87}$ with the latter being interpreted by the Court as entailing enforceable substantive and procedural obligations with a view to protecting the unity in the international representation of the EU. ${ }^{88}$

Post-Lisbon, in general, the Commission is explicitly mandated to represent the Union externally, ${ }^{89}$ without reference to the role for the rotating Presidency of the Council, which had in practice spoken for the Union and its Member States in MEA fora both to allow the Commission, informally, to draw on qualified experts from Member States and to represent Member States' political and financial interest in EU international environmental policy-making. Member States' interests in MEA negotiations have to do with the opportunity, to introduce more stringent environmental protection measures than EU minimum standards, ${ }^{90}$ and to have a voice in matters of parallel competence, ${ }^{91}$ such as finance and technology transfer, that are linked to discussions on the common but differentiated responsibilities of industrialised and developing countries under MEAs. While in the immediate aftermath of the entry into force of the Lisbon Treaty, the Commission and Member States disagreed on whether the Commission had in effect been authorized to negotiate without the Presidency in MEA fora, ${ }^{92}$ the practice of joint representation by the Commission and the Presidency, with a team approach to allow experts from different Member States to lead particular subject-specific negotiations, has continued.

\footnotetext{
${ }^{86}$ Case C-409/13 Council v Commission [2015] ECLI:EU:C:2015:217, para 64.

${ }^{87}$ Van Eeckhoutte \& Corthaut (2017) o.c. 765.

${ }^{88}$ Marin Duran \& Morgera (2012) o.c. Case C-266/03 Commission v Luxembourg [2005] ECLI:EU:C:2005:341, para 60 and Case C-433/03 Commission v Germany [2005] ECLI:EU:C:2005:462, para 66; Case C-246/07, para 104. See Christophe Hillion, 'Mixity and Coherence in EU External Relations: The Significance of the "Duty of Cooperation"' in Christophe Hillion and Panos Koutrakos (eds), Mixed Agreements Revisited. The EU and its Member States in the World (Hart 2010) 87-115. As regards the relevance of the principle of institutional balance in this context, see also Case C-425/13 Commission v Council [2015] ECLI:EU:C:2015:483, paras 90-1.

${ }^{89}$ Articles 17(1) and 27(2) TEU.

${ }^{90}$ Under Article 193 TFEU: Dashwood (2010) o.c. 364. But see case C-246/07 discussed above.

${ }^{91}$ Art. 4(3)-(4) TFEU.

${ }^{92}$ Matthias Buck, 'The EU's Representation in Multilateral Environmental Negotiations after Lisbon' in Elisa Morgera (ed), The External Environmental Policy of the European Union (Cambridge University Press 2012) 76-95; Jolyon Thomson, 'A Member State's Perspective on the Post-Lisbon Framework for the EU's Representation in Multilateral Environmental Negotiations' in Elisa Morgera (ed), The External Environmental Policy of the European Union (Cambridge University Press 2012) 96-112.
} 
In 2011, the Council endorsed the General Arrangements for EU Statements in multilateral organisations $^{93}$ that provide some guidance, even if they are deliberately vague and avoid addressing any of the most controversial aspects of the EU's representation in those forums. ${ }^{94}$ The overarching principle under which the General Arrangements are set out is that, ' $\ldots$ the preparation of statements relating to the sensitive area of competences of the EU and its Member States should remain internal and consensual. ${ }^{95}$ Accordingly, under the General Arrangements, Member States' and the EU's delegations commit to coordinating their action to the fullest extent possible, ensure the fullest possible transparency through adequate and timely prior consultation. Member States, moreover, decide on a case-by-case basis whether to agree on a common representation, and whether it is to be exerted by an EU actor or a Member State (e.g. the Member State holding the Presidency of the Council) on their behalf. ${ }^{96}$

\section{Concluding remarks}

In general terms, EU environmental law and governance may be seen as the regulatory and institutional reaction of the political and legal systems to the negative environmental externalities of the operation of the economic system. In so doing, it contributes to managing and mitigating the impact of economic activity on the environment, while promoting the conditions for economic development in the EU. Therefore, as a global actor, the EU promotes a specific understanding of sustainable development as normative paradigm of global socio-environmental governance. Its understanding of sustainability advocates an 'ecological modernization' towards a low-carbon economy, by contrast to alternative, more radical understandings thereof that question present neoliberal modes of capitalism and reproach it for past and present socio-environmental equity deficits. ${ }^{97}$ Therefore, the EU has a vested interest in ensuring over time its relevance in international environmental governance. ${ }^{98}$ It does so to globally uphold specific cultural values, rooted in liberal democracy and free-market economy, on which the Union's and its Member States' societies' reproduction are based. Grounded on economic power, as well as scientific and

\footnotetext{
${ }^{93}$ EU Statements in multilateral organisations - General Arrangements, Council Doc. 15901/11 (24 October 2011).

${ }^{94}$ Van Eeckhoutte and Corthaut (2017) o.c. 767.

${ }^{95}$ EU Statements in multilateral organisations - General Arrangements, para 2.

${ }^{96}$ Ibid, para 3.

${ }^{97}$ Burns \& Carter (2012) o.c..

${ }^{98}$ See 2016 EU Global Strategy (n 67).
} 
technological expertise, the EU seeks global environmental leadership in a growingly multipolar world through performance in intergovernmental gatherings and by driving up standards via global regulatory competition. ${ }^{99}$

The evolution of EU primary law, especially that of the provisions of the EU and FEU Treaties regarding the EU's external action that have been discussed in the previous sections have to be seen in that general context. As the paradigmatic example of the failure of the EU and its Member States in the 2009 Climate Change Summit in Copenhagen shows, the EU faces a series of challenges in order to live up to its ambition to become a global environmental leader.

Some of these challenges are, indeed, structural in nature. The complex power-sharing arrangements between the EU and its Member States in the field of environmental protection clearly adds to the complexity of EU external environmental action and demands substantial efforts of coordination in order to ensure the required consistency of action. And while the relevant EU and FEU Treaty provisions cannot possibly address all issue areas regarding the coordination and consistency of the EU's external representation, pragmatic ad hoc solutions have been found in practice, allowing for more consistent performance in international environmental negotiations over the past years. ${ }^{100}$ In this context, the Court of Justice has played a crucial role of constitutional arbitrator, ${ }^{101}$ facilitating on the one hand the articulation of bespoke, pragmatic solutions to the complexities of the EU's external representation, whilst ensuring on the other hand, their consistency with the principle of inter-institutional balance, protecting in particular the prerrogatives and autonomy of the Commission vis-à-vis the Council in international environmental negotiations, ${ }^{102}$ and the principle of loyal cooperation of Member States with the European Institutions. ${ }^{103}$

Although not discussed in this chapter, internal political factors and internal EU policy and legal developments are also very significant to understand EU external action related to the environment and to assess the EU's capacity to forward its environmental policy ambitions in international relations. On the one hand, the economic and financial crisis that has hit the EU in its recent past,.,

\footnotetext{
${ }^{99}$ Burns \& Carter (2012) o.c.

${ }^{100}$ Van Eeckhoutte \& Corthaut (2017) o.c. 809.

101 Van Eeckhoutte \& Corthaut (2017) o.c. 807.

102 Case C-425/13 [2015], paras. 90-91.

${ }^{103}$ Case C-246/07 [2010].
} 
the lowering of development aid commitments, Brexit and an uncertain economic outlook in the immediate future contribute to destabilize the international environmental ambitions of the EU and undermine its credibility as a global environmental leader. ${ }^{104}$ On the other hand, EU external action related to the environment also interact with, and is influenced by, developments in the EU's internal environmental policy and its experimentation with internal environmental instruments with extraterritorial implications. ${ }^{105}$

104 Charlotte Burns \& Paul Tobin, 'The Limits of Ambitious Environmental Policy in Times of Crisis', European Union External Environmental Policy (Springer International Publishing 2018) 319-336, 328 and 330.

${ }^{105}$ Eg, Hans Vedder, 'Diplomacy by Directive: An Analysis of the International Context of the Emissions Trading Directive' in M Evans and P Koutrakos (eds), Beyond the Established Legal Orders (Oxford: Hard Publishing, 2011) 105-124; K Kulovesi, E Morgera, and M Muñoz, 'Environmental Integration and Multi-faceted International Dimensions of EU Law: Unpacking the EU's 2009 Climate and Energy Package' (2011) Common Market Law Review 48(3), 829-891; Joanne Scott, 'Extraterritoriality and Territorial Extension in EU Law' (2014) American Journal of Comparative Law 62(1), 87-126. 